\title{
Botulinum toxin in spasmodic torticollis
}

\author{
R STELL, P D THOMPSON, C D MARSDEN \\ From the University Department of Neurology, National Hospital for Nervous Diseases, Queen Square, London \\ and The Maudsley Hospital and Bethlem Royal Hospitals, London, UK
}

SUMMARY Ten patients with spasmodic torticollis were treated by injection of a total dose of $30 \mathrm{ng}$ of botulinum toxin type A into the affected sternomastoid and posterior cervical muscles. Nine patients reported improvement in head position and control, which was confirmed in seven cases by clinical assessment and "blind" videotape ratings before and 6 weeks after injection. Five patients who had pain reported relief. Seven patients had mild transient dysphagia after injection; two who were given a more concentrated solution of the toxin developed more severe dysphagia, but this also recovered. Other minor transient side effects included weakness of the voice and local pain. The beneficial effects of botulinum toxin injections lasted some 2 to 3 months. A slight reduction in the total dose of toxin injected avoided the main side effects, and this method of treatment appears to offer successful control of head position and pain in the majority of patients with torticollis.

Spasmodic torticollis is difficult to treat. Little is known about its underlying pathogenesis, so therapy has been symptomatic.

Biofeedback and behavioural modification have been used ${ }^{12}$ but unfortunately without convincing long term success. Numerous drugs have been reported to produce benefit in some patients with torticollis, ${ }^{34}$ but few have given reliable relief and improvement occurs in only a minority of patients. Anticholinergic drugs, such as benzhexol may be of value to about $20 \%$ of patients, but side effects often restrict their use. Surgery has been directed to both the brain (stereotactic thalamotomy) and to peripheral nerves and roots. Thalamotomy ${ }^{56}$ has fallen out of favour because of inconsistency in its effects and an unacceptable risk to speech with bilateral lesions. Sections of anterior spinal roots via laminectomy carries some risk to life and the spinal cord, and may leave an unstable neck. ${ }^{7}$ Selective division of the cervical posterior primary $\mathrm{rami}^{8}$ is safe, but it is difficult to achieve complete denervation of the affected muscles. Thus, there is need for some other method of treating this distressing condition.

Botulinum A toxin is a powerful pre-synaptic neurotoxin produced by Clostridium botulinum. ${ }^{9}$ Its action is to inhibit release of acetyl choline by dis-

Address for reprint requests: Professor C D Marsden, National Hospital for Nervous Diseases, Queen Square, London WCIN 3BG, UK.

Received 5 February 1988.

Accepted 7 March 1988 rupting calcium ion metabolism in the nerve terminal. Botulinum toxin has previously been used to treat strabismus $^{10}$ and a number of other ophthalmological conditions. More recently it has been used successfully to treat blepharospasm ${ }^{1112}$ and hemifacial spasm. ${ }^{13}$ Preliminary reports from North America of its use in torticollis ${ }^{14-16}$ have been encouraging.

\section{Patients and methods}

\section{Patients}

Ten patients (6 females and 4 males) aged between 25-60 years (mean 49.2) were treated. Disease duration ranged from 9 months to 14 years (mean 5.8 years). Six patients had torticollis alone; three had segmental dystonia ( 2 cervicobrachial and one cranio-cervical); and one had generalised dystonia. Five patients had localised neck pain associated with their torticollis. All continued their usual medication, provided it had not been commenced within the preceding 2 weeks.

\section{Assessments}

Patients were rated (RS) before and 3 and 6 weeks after treatment according to the scale used previously by Tsui et al. ${ }^{14}$

(A) Amplitude of sustained movements: rotation, tilt and antero-posterior deviation of the head was scored individually as: $0=$ absent, $1=$ less than $15^{\circ}, 2=15-30^{\circ}, 3=$ more than $30^{\circ}$. The three scores were summed.

(B) Duration of sustained movements: $1=$ intermittent; $2=$ constant

(C) Shoulder elevation: $0=$ absent; $1=$ mild and intermittent; 2 = mild and constant, or severe and intermittent; $3=$ severe and constant. 
(D) Tremor: its severity: $1=$ mild; $2=$ severe, was multiplied by its duration: 1 = occasional; 2 = continuous.

Total score $=(A) \times(B)+(C)+(D)$.

Patients were then videotaped, according to a standardised protocol, at rest and whilst walking, before treatment and 3 and 6 weeks after treatment. At the end of the study the videos were randomised and assessed independently by two "blind" examiners (CDM, PT) according to the following scale:

(1) Severity of torticollis (0-4) at "rest" for both (a) deviation and (b) jerks.

(2) Severity of torticollis (0-4) on talking, holding the arms outstretched, and walking for both (a) deviation and (b) jerks.

Total score $=(1)+(2)$.

\section{Botulinum toxin injections}

Following their initial videotape, patients were studied electromyographically using surface electrodes over both sternomastoid and trapezius muscles, and with needle electrodes in each splenius capitus. The patients were examined at rest and with maximal effort on voluntary head movement in all planes. On the basis of these recordings the two most active muscles were selected for injections. Six patients had typical rotational torticollis, and the muscles injected were ipsilateral splenius capitus and contralateral sternomastoid. The other four had more complex movements of the neck, but the most active sternomastoid and splenius capitus were injected in each case.

Botulinum A toxin was obtained from the Vaccine Research and Production Laboratory, Porton Down, UK. Each ampoule contained $50 \mathrm{ng}$ of freeze dried neurotoxin, bound to haemaglutinin. This was reconstructed with $10 \mathrm{ml}$ of sterile normal saline in the first eight patients. This solution $(1.5 \mathrm{ml})$ was then injected into two separate sites of each selected muscle so that each muscle received a total of $3 \mathrm{ml}$ of the solution ( $15 \mathrm{ng}$ toxin). The total dose was $30 \mathrm{ng}$ toxin per patient. In patients 8 and 9 (table 1 ) the ampoule was diluted into $5 \mathrm{ml}$ of normal saline, and $0.75 \mathrm{ml}$ was injected into two separate sites of each selected muscle; again each muscle received $15 \mathrm{ng}$ toxin and each patient received a total dose of $30 \mathrm{ng}$ toxin.

This dosage represents six times the total dose used previously to treat blepharospasm using the same preparation of the toxin. ${ }^{12}$ This compares with trials in the USA where the dosage used to treat torticollis ${ }^{14}$ was approximately four times that employed to treat blepharospasm. ${ }^{11}$

After injection patients were observed in hospital for 3 days and then discharged. One week after injection patients reported benefits and side effects (if any) by telephone. Patients were then reviewed at 3-weekly intervals by one of us (RS), at which time they were re-videotaped and re-scored after physical examination. Follow-up continued until there was objective evidence of relapse or for a maximum period of 16 weeks. Patients also were asked to rate their improvement on a scale of $0-3$ (0 being no improvement, $1=$ mild, 2 = moderate, $3=$ marked improvement) at 3-weekly intervals.

\section{Results (table 1)}

Using the paired Student's $t$ test there was a significant $(p<0.01)$ reduction in the scores of severity for all 10

Table 1 Effect of botulinum toxin on assessments of torticollis

\begin{tabular}{|c|c|c|c|c|c|c|c|c|c|c|}
\hline \multirow{2}{*}{$\begin{array}{l}\text { Patient } \\
\text { no. }\end{array}$} & \multicolumn{2}{|c|}{ Clinical score ${ }^{1}$} & \multicolumn{2}{|c|}{ Videotape score ${ }^{2}$} & \multirow{2}{*}{$\begin{array}{l}\text { Self assessment }{ }^{3} \text { of } \\
\text { improvement }(6 \mathrm{wk})\end{array}$} & \multicolumn{2}{|l|}{ Pain $^{4}$} & \multirow{2}{*}{$\begin{array}{l}\text { Duration of } \\
\text { benefit (wk) }\end{array}$} & \multirow{2}{*}{$\begin{array}{l}\text { Onset of } \\
\text { benefit }\end{array}$} & \multirow{2}{*}{$\begin{array}{l}\text { Peak } \\
\text { effect }\end{array}$} \\
\hline & Before & After (6 wk) & Before & After (6wk) & & Before & $\overline{A f t e r}(6 w k)$ & & & \\
\hline 1 & 8 & 3 & $\begin{array}{l}4 \cdot 5 \\
5\end{array}$ & $\begin{array}{l}1 \\
2\end{array}$ & 3 & 0 & $\mathbf{0}$ & 15 & $2 \mathrm{wk}$ & 3 wk \\
\hline 2 & 16 & 6 & $\begin{array}{l}7 \\
7\end{array}$ & $\begin{array}{l}5 \\
5\end{array}$ & 2 & 0 & 0 & 12 & 1 wk & 2 wk \\
\hline 3 & 9 & 8 & $\begin{array}{l}7 \cdot 5 \\
7\end{array}$ & $\begin{array}{l}5 \\
7 \cdot 5\end{array}$ & 1 & 2 & 0 & 8 & 1 wk & $2 w k$ \\
\hline 4 & 11 & 5 & $\begin{array}{l}10 \\
10\end{array}$ & $\begin{array}{l}4 \cdot 5 \\
4\end{array}$ & 2 & 3 & 0 & 8 & 6 days & $1 \mathrm{wk}$ \\
\hline 5 & 11 & 7 & $\begin{array}{l}6 \\
9\end{array}$ & $\begin{array}{l}2 \\
2 \cdot 5\end{array}$ & 3 & 0 & 0 & 13 & 10 days & 10 days \\
\hline 6 & 17 & 10 & $\begin{array}{r}9 \cdot 5 \\
11 \cdot 5\end{array}$ & $\begin{array}{r}7 \cdot 5 \\
11 \cdot 0\end{array}$ & 2 & 0 & 0 & 12 & $1 \mathrm{wk}$ & $2 w k$ \\
\hline 7 & 7 & 6 & $\begin{array}{l}6 \\
7\end{array}$ & $\begin{array}{l}8 \\
6\end{array}$ & 0 & 3 & 1 & 8 & - & - \\
\hline 8 & 7 & 5 & $\begin{array}{l}7.0 \\
7.5\end{array}$ & $\begin{array}{l}2 \cdot 5 \\
3 \cdot 5\end{array}$ & 3 & 3 & 0 & 10 & $1 \mathrm{wk}$ & $1 \mathrm{wk}$ \\
\hline 9 & 9 & 9 & $\begin{array}{l}5 \\
6\end{array}$ & $\begin{array}{l}4 \\
7 \cdot 5\end{array}$ & 2 & $\mathbf{0}$ & $\mathbf{0}$ & 8 & 4 days & $1 \mathrm{wk}$ \\
\hline 10 & 16 & 4 & $\begin{array}{l}11.5 \\
11.5\end{array}$ & $\begin{array}{l}5 \\
5 \cdot 5\end{array}$ & 2 & 3 & 0 & 10 & 4 days & $1 \mathrm{wk}$ \\
\hline Mean & $11 \cdot 1$ & $6 \cdot 3^{*}$ & $7 \cdot 8$ & $4.9^{*}$ & 2 & 1.4 & $\mathbf{0}$ & $10 \cdot 4$ & 6.6 days & $10 \cdot 1$ days \\
\hline
\end{tabular}

${ }^{1}$ On the scale of Tsui et al (14), see Methods.

${ }^{2}$ The scores of each of the two "blind" raters is shown. For statistical analysis, the mean of the two scores was used.

${ }^{3}$ Self-rating by patients of benefit on scale of 0 (no benefit) to 3 (marked) 6 weeks after injection.

${ }^{4}$ Self-rating of pain in neck on scale of 0 (nil) to 3 (severe).

*Paired Student's $t$ test: $\mathrm{p}<0.01$. 
patients 6 weeks after injection on both "blind" video assessment and clinical assessment. Head position and control was improved in seven patients (Nos 1, 2, 4, $5,6,8,10)$ on all scores of both the video assessment and physical examination. One patient (No 7) was judged to have improved on physical examination, but not on videotape assessment. This patient had a tremulous variably-directed torticollis, with severe right-sided neck pain. However, the patient reported almost complete resolution of neck pain.

Two patients (Nos 3, 9) reported some improvement in their neck position and control, but the results of clinical and videotape assessment were inconsistent. Patient 3 had segmental dystonia which followed 2.5 years of treatment with phenothiazines for endogenous depression. The patient had marked variable torticollis which was exacerbated greatly by standing and walking. Although neck position did not improve, his pain did. Patient 9 also had segmental dystonia with marked retrocollis at rest and on walking.

Improvement appeared from 4 days to 2 weeks (mean 6.6 days) after injection, and reached its peak from 10 days to 3 weeks (mean 10.1 days). The duration of improvement measured from its onset until the first evidence of deterioration ranged from 8 to 15 weeks (mean 10.4 weeks).

In total, five patients had neck or shoulder pain prior to treatment. This pain was completely relieved in four cases, and in the other it was greatly improved so that oral analgesics were no longer required. Relief of pain began 4-7 days after injection. Pain recurred in all five patients when head position and control deteriorated.

Side effects were experienced to some degree by all patients (table 2). The most common was dysphagia which occurred in nine patients. This was mild in seven, producing minimal disability, and noted mainly with dry solids. In patients 8 and 9 dysphagia was severe with difficulty swallowing saliva, liquids and solids. Attempts to swallow anything but sips of water produced aspiration and coughing. Patient 9 had a previous history of intermittent choking on solids though not liquids for some years, but had not been investigated for this previously. Both patients were admitted for observation 2 to 3 weeks after injection. Neither required rehydration. Nutrition was provided by using the semi-solid food supplement "Complan" which was well tolerated. In patient 8 , a barium swallow was normal, but laryngoscopy revealed pooling of saliva in the pyriform fossa and reduced motility of the right vocal cord. In patient 9 , there was pooling of barium in the oropharynx with prominent aspiration of barium, but oesophageal contractility was normal. Laryngoscopy revealed considerable saliva pooling and a right vocal cord paralysis. In both patients repeated laryngoscopy 3 weeks later demonstrated complete recovery of vocal cord motility. Both these patients had received botulinum toxin into their left sternomastoid and right splenius capitus muscles in the same manner as in other patients, except that in these two the solution was more concentrated (the same total dose being dissolved in half the volume).

In general, dysphagia began 2-10 days after injection and lasted 4 days to 1 month; complete resolution occurred in all patients.

Five patients complained of dysphonia. This was mild and consisted of a slight deepening and reduction in volume of the voice. It began 2-7 days after injection, and lasted for a maximum of 6 weeks.

Two patients complained of transient dryness of the throat, two complained of generalised asthenia without weakness, and one patient complained of

Table 2 Side effects

\begin{tabular}{|c|c|c|c|c|}
\hline \multirow[b]{2}{*}{ Patient } & \multirow[b]{2}{*}{ Side effect } & \multirow[b]{2}{*}{ Severity } & \multicolumn{2}{|c|}{1 week post-injection } \\
\hline & & & Onset & Duration \\
\hline 1 & $\begin{array}{l}\text { Hypophrenia } \\
\text { Dysphagia }\end{array}$ & $\begin{array}{l}\text { Mild } \\
\text { Mild for dry food }\end{array}$ & $\begin{array}{l}2 / 7 \\
2 / 7\end{array}$ & $\begin{array}{l}3 \text { weeks } \\
3 \text { weeks }\end{array}$ \\
\hline 2 & $\begin{array}{l}\text { Dry mouth } \\
\text { Dysphagia }\end{array}$ & $\begin{array}{l}\text { Minimal } \\
\text { Mild for solids only }\end{array}$ & $\begin{array}{l}1 / 7 \\
1 \text { week }\end{array}$ & $\begin{array}{l}1 \text { week } \\
4 \text { weeks }\end{array}$ \\
\hline 3 & Dysphagia & Mild-dry food, occasionally liquids & 1 week & 10 days \\
\hline 4 & $\begin{array}{l}\text { Dysphagia } \\
\text { Generalised tiredness }\end{array}$ & $\begin{array}{l}\text { Mild-only dry food } \\
\text { Could continue to go to work }\end{array}$ & $\begin{array}{l}2 \text { days } \\
2 \text { days }\end{array}$ & $\begin{array}{l}4 \text { weeks } \\
6 \text { weeks }\end{array}$ \\
\hline 5 & Dysphagia & One or two occur only for dry food & $1-5$ weeks & 4 days \\
\hline 6 & $\begin{array}{l}\text { Dysphagia } \\
\text { Hypophrenia }\end{array}$ & $\begin{array}{l}\text { Mild difficulty swallowing meat } \\
\text { Difficulty monitoring volume when singing }\end{array}$ & $\begin{array}{l}1 \text { week } \\
1 \text { week }\end{array}$ & $\begin{array}{l}2 \text { weeks } \\
2 \text { weeks }\end{array}$ \\
\hline 7 & $\begin{array}{l}\text { Dysphagia } \\
\text { Hypophrenia }\end{array}$ & $\begin{array}{l}\text { Dry bread and meat (mild) } \\
\text { Softer voice }\end{array}$ & $\begin{array}{l}5 \text { days } \\
5 \text { days }\end{array}$ & $\begin{array}{l}1 \text { week } \\
2 \text { weeks }\end{array}$ \\
\hline 8 & $\begin{array}{l}\text { Dysphagia } \\
\text { Hypophrenia } \\
\text { Generalised tiredness }\end{array}$ & $\begin{array}{l}\text { Moderately one, liquids and solids, "Complan" } \\
\text { Soft horse voice } \\
\text { "Sleeping all the time" }\end{array}$ & $\begin{array}{l}2 \text { days } \\
1 \text { week } \\
2 \text { weeks }\end{array}$ & $\begin{array}{l}4 \text { weeks } \\
4 \text { weeks } \\
4 \text { weeks }\end{array}$ \\
\hline 9 & $\begin{array}{l}\text { Dysphagia } \\
\text { Hypophrenia }\end{array}$ & $\begin{array}{l}\text { Severe; unable to swallow liquids or solids } \\
\text { Very soft voice }\end{array}$ & $\begin{array}{l}2 \text { days } \\
1 \text { week }\end{array}$ & $\begin{array}{l}4 \text { weeks } \\
6 \text { weeks }\end{array}$ \\
\hline 10 & $\begin{array}{l}\text { Dry throat } \\
\text { Pain at site of trapezius injection }\end{array}$ & $\begin{array}{l}\text { Mild } \\
\text { Moderate }\end{array}$ & $\begin{array}{l}1 \text { week } \\
2 \text { days }\end{array}$ & $\begin{array}{l}2 \text { days } \\
4 \text { days }\end{array}$ \\
\hline
\end{tabular}


localised pain and tenderness at the injection sites lasting 4 days.

\section{Discussion}

This open trial (with "blind" videotape assessments) using botulinum toxin confirms previous reports ${ }^{14-16}$ claiming its usefulness in the treatment of torticollis. Seven of 10 patients improved on videotape and clinical assessment of head position and control. Two further patients reported better control of their neck, although formal assessment did not demonstrate this convincingly. Only one patient, with a variablydirected torticollis and head tremor had no benefit at all with regard to head control, but pain was improved. Pain was dramatically relieved in all five cases with this complaint.

Side effects in our trial were more frequent than in previous studies. Mild and transient dysphagia occurred in seven of the 10 patients, but was only disabling in a further two cases. Both were treated with a more concentrated solution of toxin, and it may have been that the higher gradient of solute facilitated toxin diffusion into the subjacent pharyngeal plexus and muscles when injecting the sternomastoid. However, it is difficult to explain why both developed a right vocal cord paresis after the left sternomastoid and right splenius capitus injections. It seems unlikely that local spread of toxin from these muscles could involve the right pharyngeal plexus. Retrograde transport of botulinum toxin has been previously reported, ${ }^{17}$ as has transynaptic spread of toxin with entry into the spinal cord, ${ }^{18}$ but the biological significance of this is not known. Despite the disability noted by the two most severely affected patients, neither required parenteral nutrition, and both recovered completely several weeks before the beneficial effects of the toxin waned. Other side effects, including dysphonia, dry throat, lethargy and local pain, were mild and recovered completely within a few weeks.

The frequency of side effects in our trial was most likely the result of using a relatively high dose of toxin. The dosage used was empirical, based on the dose employed in North America to treat blepharospasm and torticollis, and our own previous experience of treating blepharospasm. However, the toxin employed in the United States is not bioequivalent to that produced in this country and it is now clear that a lower dose should be used to treat torticollis in the United Kingdom. Based on our experience in the trial we now employ a total dose of $25 \mathrm{ng}$ of toxin in males, and $20 \mathrm{ng}$ in females (who have thinner necks), which has eliminated the side effects apart from local pain at the site of injection.

Botulinum toxin appears to be the most effective treatment for torticollis available at present. However, further experience is necessary to define which subgroups of patients are likely to gain the greatest benefit. At present it appears that those with true rotational torticollis and those with pain are easy to treat. Modification of the technique may extend its value to those with more complex head movements.

\section{References}

1 Brierly H. The treatment of hysterical spasmodic torticollis by behaviour therapy. Behav Res Ther 1967;5:139.

2 Brudny J, Grynbaum B, Korein J. Spasmodic torticollis treatment by feedback display of the EMG. Arch Phys Med Rehab 1974;55:403-8.

3 Fahn S. Treatment of dystonia with high-dosage anticholinergic medication. Neurology 1979;29:605.

4 Fahn S, Marsden CD. The treatment of dystonia. In: Marsden CD, Fahn S, eds. Movement Disorders 2, London Butterworths International Medical Reviews 1987:362-7.

5 Cooper IS. Neurosurgical treatment of the dyskinesias. Clin Neurosurg 1977;24:367-90.

6 Andrew RL, Fowler CJ, Harrison MJG. Stereotaxic thalamotomy in 55 cases of dystonia. Brain 1983; 106:981-1000.

7 Maccabe JJ. Surgical treatment of spasmodic torticollis. In: Marsden CD, Fahn S, eds. Movement Disorders, London Butterworths International Medical Reviews 1982:308-14.

8 Bertrand CM, Molina-Negro P. Selective peripheral nerve denervation in 111 cases of spasmodic torticollis. Adv Neurol 1988;50:637-43.

9 Drachman DB, Kao I, Price DL. Botulinum toxin: Mechanisms of presynaptic blockade. Science 1976; 193:1256-8.

10 Scott AB. Botulinum toxin injection of eye muscles to correct strabismus. Trans Am Ophthal Soc 1981; LXXIX:734-70.

11 Scott AB, Kennedy RA, Stubbs HA. Botulinum toxin injection as a treatment for blepharospasm. Arch Ophthalmol 1985;103:347-50.

12 Elston JS, Russell RW. Effect of treatment with botulinum toxin on neurogenic blepharospasm. $\mathrm{Br}$ Med J 1985;290:1857-59.

13 Mauriello JA. Blepharospasm, Meige's syndrome and hemifacial spasm: Treatment with botulinum toxin. Neurology 1985;35:1499-500.

14 Tsui JK, Eisen A, Stoessl A, Calne S, Calne DB. Doubleblind study of botulinum toxin in spasmodic torticollis. Lancet 1986;ii:245-6.

15 Brin MF, Fahn S, Moskowitz CB, et al. Injection of botulinum toxin for the treatment of focal dystonia. Neurology 1986;36 (suppl 1): 120.

16 Jankovic J, Orman J. Botulinum A toxin for cranialcervical dystonia: a double-blind, placebo-controlled study. Neurology 1987;37:616-23.

17 Black JD, Dolly JO. Interaction of ${ }^{125}$ I-labelled botulinum neurotoxins with nerve terminals. I: Ultrastructural autoradiographic localisation and quantitation of distinct membrane receptors for types $A$ and B on motorneurones. J Cell Biol 1986; 103:521-34.

18 Wiegand H, Erdmann G, Wellhoner HH. ${ }^{125} \mathrm{I}$-labelled botulinum $\mathrm{A}$ neurotoxin: pharmacokinetics in cats after intramuscular injection. Naunyn-Schmiedebergs Arch Pharmacol 1976;292:161-5. 